\title{
Discovery and description of nymphal stages of a heterozerconid mite (Acari: Mesostigmata: Heterozerconidae) from coastal forest litter in southeastern São Paulo State, Brazil*
}

\author{
GERALD W. KRANTZ \& GILBERTO J. DE MORAES ${ }^{2}$ \\ 'Department of Zoology, Oregon State University, Corvallis, OR 97331 USA; \\ E-mail: krantzg@science.oregonstate.edu \\ ${ }^{2}$ Departamento de Entomologia e Acarologia, ESALQ-USP, Piracicaba, São Paulo, Brazil, \\ E-mail:gjmoraes@esalq.usp.br
}

* In: Moraes, G.J. de \& Proctor, H. (eds) Acarology XIII: Proceedings of the International Congress Zoosymposia, 6, 1-304.

\begin{abstract}
Free-living mesostigmatic mites collected in coastal forest litter samples in southeastern Brazil were determined to be the nymphal stages of an unknown species of Heterozerconidae, a family whose adults are typically associated with millipedes (Diplopoda) and, less commonly, with squamate reptiles. This is only the second published record of immature heterozerconids and the first positive determination of field-collected heterozerconid nymphs for which the adults have yet to be identified. The protonymph and deutonymph are described, unique morphological characters are discussed, and inferences are made as to the possible identity of the adult stage and its host.
\end{abstract}

Key words: Heterozerconidae, Diplopoda, Squamata, Brazil

\section{Introduction}

Routine examination of litter from a coastal forest near Cananéia, São Paulo State, Brazil, in 2000 and 2001 resulted in the recovery of immatures of a mesostigmatic mite that initially defied our attempts to identify them. Live specimens examined under a stereoscopic microscope were easily distinguished from other mites in the samples by several very long, distally sinuous marginal and dorsal setae that were arched over the idiosoma as if in a protective mode, and by the relatively long first pair of legs provided with some long setae (Fig. 1). The presence of an interdigital membrane on the chelicerae and acrotarsi on legs I led us to conclude that the unknown nymphs represented a species of the early derivative Heterozerconidae, a family whose immatures were previously unknown. The appearance shortly afterwards of a landmark paper by Gerdeman \& Klompen (2003) describing both immature and adult stages of a new genus and species of heterozerconid mite, Narceoheterozercon ohioensis Gerdeman \& Klompen, from the nest of a spirobolid millipede in Ohio, USA, confirmed our conclusion.

Heterozerconid mites are remarkable in a number of ways. Their unusual morphology sets them apart from other Monogynaspida to the extent that they are typically grouped in a separate cohort, the Heterozerconina, a taxon which they share with the equally bizarre, centipede-associated family Discozerconidae (Lindquist et al., 2009). Like many antennophorine Trigynaspida, adult heterozerconids may be associated either with invertebrate or vertebrate hosts. In fact, some believe that the Heterozerconina may be the sister group of the Trigynaspida s. lat. (Norton et al., 1993), although DNA sequencing data suggests that the Heterozerconidae and Discozerconidae are two of five families comprising the suborder Sejida (Lekveishvili \& Klompen, 2004).

Among their more exceptional morphological traits, adult Heterozerconidae possess paired posteroventral sucker-like adhesive discs that may be involved in host attachment (Gerdeman \& 


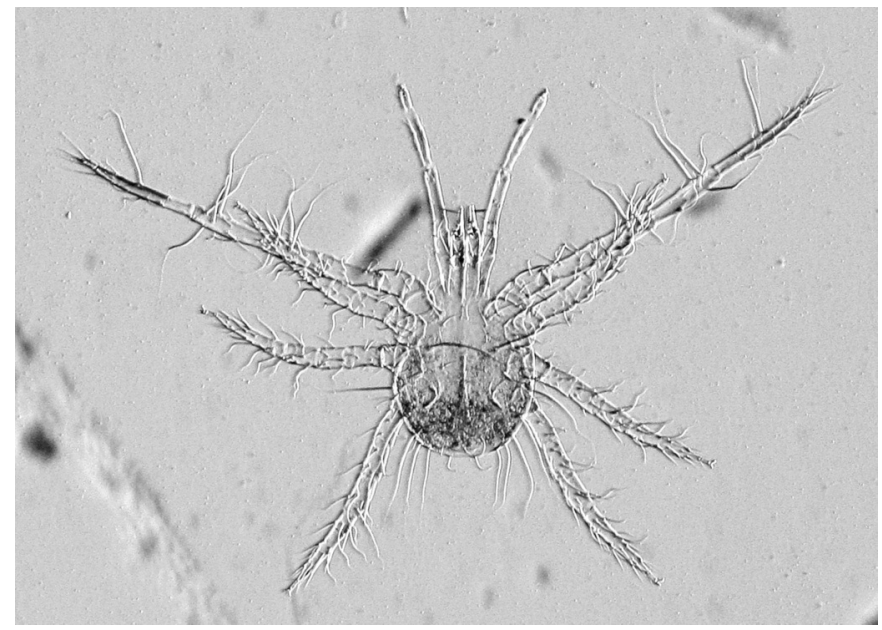

FIGURE 1. Habitus (ventral) of slide-mounted protonymph of unidentified Heterozerconidae from CananéiaSP, Brazil.

Alberti, 2007) and acrotarsi on legs I (an attribute shared with other early derivative Mesostigmata and some Holothyrida, and with deutonymphs of some Parasitidae). In addition, most known species lack one or two pairs of sternal lyrifissures (Fain, 1989). Especially noteworthy in the male is the presence of a cheliceral sperm transfer process that arises on the fixed digit rather than on the movable digit as seen in male Dermanyssina (a spermatostylus as contrasted to a dermanyssine spermatodactyl). Also exceptional is the ultrastructure of heterozerconid sperm, the morphology of which suggests that podospermy in this family has evolved independently from that of the Dermanyssina (Alberti et al., 2007).

The biology of heterozerconids is no less interesting than their morphology. Aside from a few species that have been reported from centipedes (Berlese, 1910), termite nests (Berlese \& Leonardi, 1901), beneath tree bark (Berlese, 1888), and from soil (Vitzthum, 1926), most adult heterozerconids are considered to be paraphagic on millipedes, while others are likely parasites of reptiles (Finnegan, 1931; Lizaso, 1979; Fain, 1989; Flechtmann \& Johnston, 1990; Lindquist et al., 2009). The immatures of $N$. ohioensis, the only heterozerconid species for which immatures have been described, are predators in the aggregation sites or "nests" of the millipede species that serve as hosts for their adults (Gerdeman et al., 2000). There are parallels here (albeit conversely) with the prostigmatic cohort Parasitengonina, in which the larvae generally are host-associated and the deutonymphal and adult forms are free-living predators (Walter et al., 2009). Also, as in the Parasitengonina, there is great morphological disparity between immature and adult heterozerconids, a disparity so pronounced that verification of conspecificity between a field-collected immature (i.e., one collected outside the nest habitat) and its host-associated adult may be possible only through successful rearing of the immature to the adult stage, or through application of DNA sequencing protocols involving both the immature and its suspected conspecific adult. Adults of Heterozercon and Amheterozercon species have been described from southern Brazil on millipedes and squamate reptiles respectively (Lizaso, 1979; Fain, 1989; Flechtmann \& Johnston, 1990); the genus Maracazercon Fain, erected for a species taken from a millipede on Ilha de Maraca (probably Ilha de Maracá, Roraima State) in northern Brazil (Fain, 1989), may be represented in southern Brazil as well. Clearly, the identity of immatures collected in that region cannot be assumed on empirical evidence alone. In light of the close association of $N$. ohioensis 
immatures and adults with nests of their millipede associate (Gerdeman et al., 2000), it is noteworthy that the nymphs collected near Cananéia were found in surface litter habitats well removed from recognizable millipede nests.

Gerdeman \& Klompen described heterozerconid immatures for the first time from a nest of a millipede in 2003. Here we are describing, also for the first time, field-collected immatures of a heterozerconid species whose adults have yet to be identified.

\section{Materials and Methods}

The original collections were obtained during the spring of 2000 and of 2001 from forest litter taken from a disturbed, periodically flooded area approximately $5 \mathrm{~km}$ northeast of Cananéia, SP,

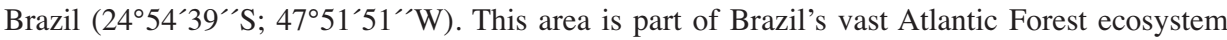
(Mata Atlântica) and is designated as a "restinga", a coastal habitat of trees and underlying vegetation anchored in a stabilized sandy soil substrate (Joly et al., 1999). Collected litter samples were placed in plastic bags and transported to Departmento de Entomologia e Acarologia at ESALQ, Piracicaba, SP, for Berlese funnel extraction. Mites were extracted and examined under a stereomicroscope. A number of unusual specimens with long, distally sinuous dorsal setae and elongate, terminally tanned legs I were slide-mounted in Hoyer's medium for closer examination under a compound microscope, utilizing methods outlined in Walter \& Krantz (2009a). After verifying that they were nymphal forms and while we were attempting to establish their family identity, we transferred some specimens to covered glass petri dishes $(9 \mathrm{~cm})$ in order to observe their behavior. The dishes were provided with a substrate of fresh litter taken from the site where the mites had been originally collected, and its initial high moisture level was maintained through periodic addition of distilled water. The litter substrate contained many nematodes and other organisms including representatives of the suborder Oribatida and of the mite families Eupodidae, Rhodacaridae, Uropodidae, and Ologamasidae. Termites also were present, and freshly crushed individuals were added to the substrate as a possible food source. The substrate material was replaced periodically with fresh litter during the two week period that dishes were maintained. Feeding was never observed, and when nymphs finally died without molting to the next stage, they were placed in $70 \%$ ethyl alcohol for later mounting in Hoyer's solution (Walter \& Krantz, 2009a). Additional litter samples were taken from the sampling site on several occasions between 2003 and 2011, but few specimens were recovered from these collections.

Observations on live material were conducted at ESALQ under a MZ8 Leica stereomicroscope. Descriptions and illustrations of slide-mounted material were carried out at Oregon State University, Corvallis, with a Zeiss laboratory phase contrast microscope equipped with a Zeiss drawing tube. A Leica DMRB photomicroscope equipped with an RT Spot digital camera (Diagnostic Instruments, Inc.) was used to photograph the deutonymphal prodorsal shield. Measurements cited in the descriptions are in micrometers.

\section{Descriptions}

The following descriptions are based on two deutonymphs and six protonymphs collected from forest litter at the site described above. The identities of some idiosomatic and leg setae are unclear or uncertain, and no attempt has been made to provide complete chaetotaxies for either idiosoma or appendages. Setae that are identified in the descriptions and illustrations do not always correspond to those provided by Gerdeman \& Klompen (2003) for nymphs of N. ohioensis, but there is general agreement between the two treatments. 
DEUTONYMPH (Figs. 2-4). Idiosoma more or less rounded, somewhat longer than broad [length 560-650, width 510-550 $(\mathrm{n}=2)$ ].

Dorsum (Fig. 3A) with many long and distally sinuous anterior and marginal setae (see below), other dorsal setae generally minute and simple; dorsal integument finely striate anteriorly and anterolaterally, transforming to a rough reticulate pattern posteriorly. With a peltate, evenly reticulate prodorsal shield (length 240, width 245) that clearly differs from the surrounding striate/rough reticulate integument (Figs. 3A, 4), with a number of anterolateral sigilla and a narrow, elongate median depression that extends for most of the shield length and terminates at or near posterior margin; shield with three pairs of setae (j4-6) and a pair of gland openings ( $g$ dj5 of Gerdeman \& Klompen, 2003). Podonotum with 10 pairs of setae, including those of shield (an additional minute accessory seta, seen only on one side of available specimens, inserted in marginal integument laterad from $j 6$ ); opisthonotum with 15 pairs of setae. Podonotal setae $j 1$ and $s 1$ absent. Setae $j 2, j 3$, $j 5, \mathrm{z} 4-5, \mathrm{~s} 4, s 6, S 3$, and Z2-4 elongate to greatly elongate (185-460) and distally sinuous, $S 1-2$ and $Z 5$ shorter than other marginals (as in deutonymph of $N$. ohioensis) but considerably longer than the remaining dorsal setae; $J 1$ present ( $J 2$ of Gerdeman \& Klompen, 2003), $J$ series minute; with three similarly minute opisthonotal accessory setal pairs laterad from the $J$ series.

Venter (Fig. 3B) without sternal or ventral sclerites, with a general pattern of integumental striae that are largely vertical between $s t 2$, differing from adjacent, laterally oriented striae; with a well developed 2-tined laciniate tritosternum inserted at level between coxae I-II. Sternal, ventral, and opisthogastric setae elongate, smooth or weakly barbed; st $1-2$ with associated lyrifissures (iv1, iv2 of Gerdeman \& Klompen, 2003), iv3 apparently absent, st3-5 somewhat shorter than $s t 1-2$, iv5 located between insertions of $s t 5$ and $Z v 2$; opisthogastric setae $J v 1, J v 2$ and $Z v 2$ similar in length to sternals, clearly shorter than $Z v 3$ and $J v 5$; putative $R 4$ not dorsal or minute as in protonymph (Fig. 5A), slightly shorter than adjacent $Z v 3$ and inserted lateroventrally; $S 4-5$ considerably longer than adjacent setae, $S 5$ distally sinuous. With a large, clearly defined anal shield, rounded but somewhat broader than long, paranal setae inserted at posterior angles of elongate anal opening, paranal insertions bordered posteriorly by paired lyrifissures (ivp of Gerdeman \& Klompen, 2003); postanal seta shorter than paranals, inserted on anterior edge of a broad spiculate cribrum, lateromarginal cribral solenostomes (probably gv3 of Gerdeman \& Klompen, 2003) well developed, laterad from paranal insertions and marginal on the shield.

Peritremes (Fig. 3B, E) short (ca 50) and lying laterad from coxae; stigma opening posteriorly on peritreme.

Gnathosoma similar to that of protonymph (Fig. 5F); gnathotectum broad, truncate distally, anterior margin strongly spiculate (as in Fig. 5D); subcapitular hypostome with three pairs of setae, hyp 2 distinctly longer than hyp 1 and 3 and inserted well laterad from them, hyp 2-3 and capitular setae lightly pectinate; with six rows of deutosternal denticles, the most distal three each comprising a single pair of conical or obtuse "teeth"; internal malae membranous, extending nearly to the level of palptrochanteral/femoral suture, antiaxial margins finely barbed; corniculi setate, paraxial margins weakly pectinate. Chelicerae similar to those of protonymph (Fig. 5G) except in size; total length 295 including basal segment (not illustrated in figure), length of second cheliceral segment (including fixed digit) 160, movable digit 85; fixed digit with two adjacent teeth in basal portion and a broad, distally acute, membranous pilus dentilis arising dorsad from them; dorsal seta narrow, setiform, inserted between the more dorsally placed and poorly defined lyrifissure $i d$ and lyrifissure $i a$, which opens at base of digit. Movable digit edentate, with a distinctive membranous basal distension whose 18-20 bacilliform processes form a distinctive marginal comb; with a pair of long (30-35) lateroventral setiform processes arising medioventrally on the digit and a broad, marginally fimbriate interdigital membrane that has its origins at the base of the digit. Palpi similar to those of protonymph, unusually long and antennate (length 550), nearly half the length of legs I; palpfemur 3 times the length of palptrochanter (214 vs 70), and palpgenu more 


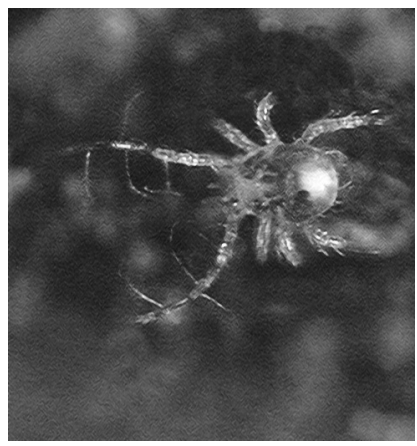

FIGURE 2. Live deutonymph of unidentified Heterozerconidae from Cananéia-SP, Brazil in observation cell, showing elevated and arched legs I and long setae of the three distal segments.

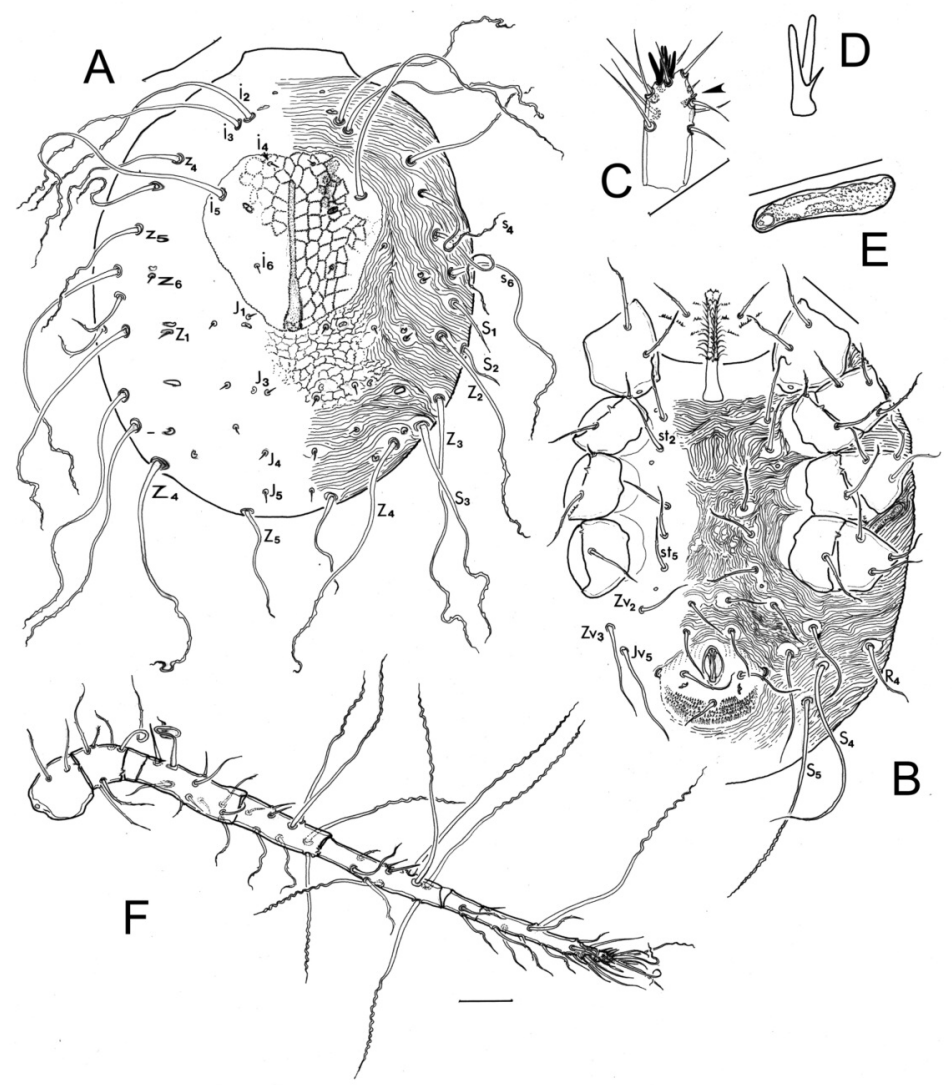

FIGURE 3. Deutonymph of unidentified Heterozerconidae from Cananéia-SP, Brazil. (A) Dorsum (scale bar $=100 \mu \mathrm{m}$ ); (B) Venter (scale bar $=100 \mu \mathrm{m}$ ); (C) Palpal tibiotarsus (arrow identifies undifferentiated palpal apotele) (scale bar $=50 \mu \mathrm{m}$ ); (D) Schematic of terminal bifurcate process on tibiotarsus; (E) Peritreme (scale bar=50 $\mu \mathrm{m})$; (F) Leg I (scale bar= $100 \mu \mathrm{m})$. 


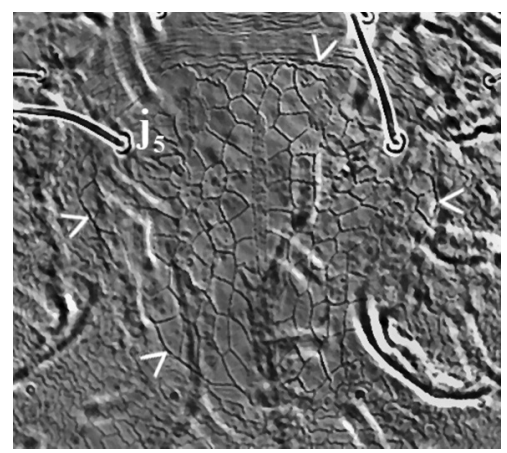

FIGURE 4. Prodorsal shield of deutonymph of unidentified Heterozerconidae from Cananéia-SP, Brazil (arrows mark the shield margin).

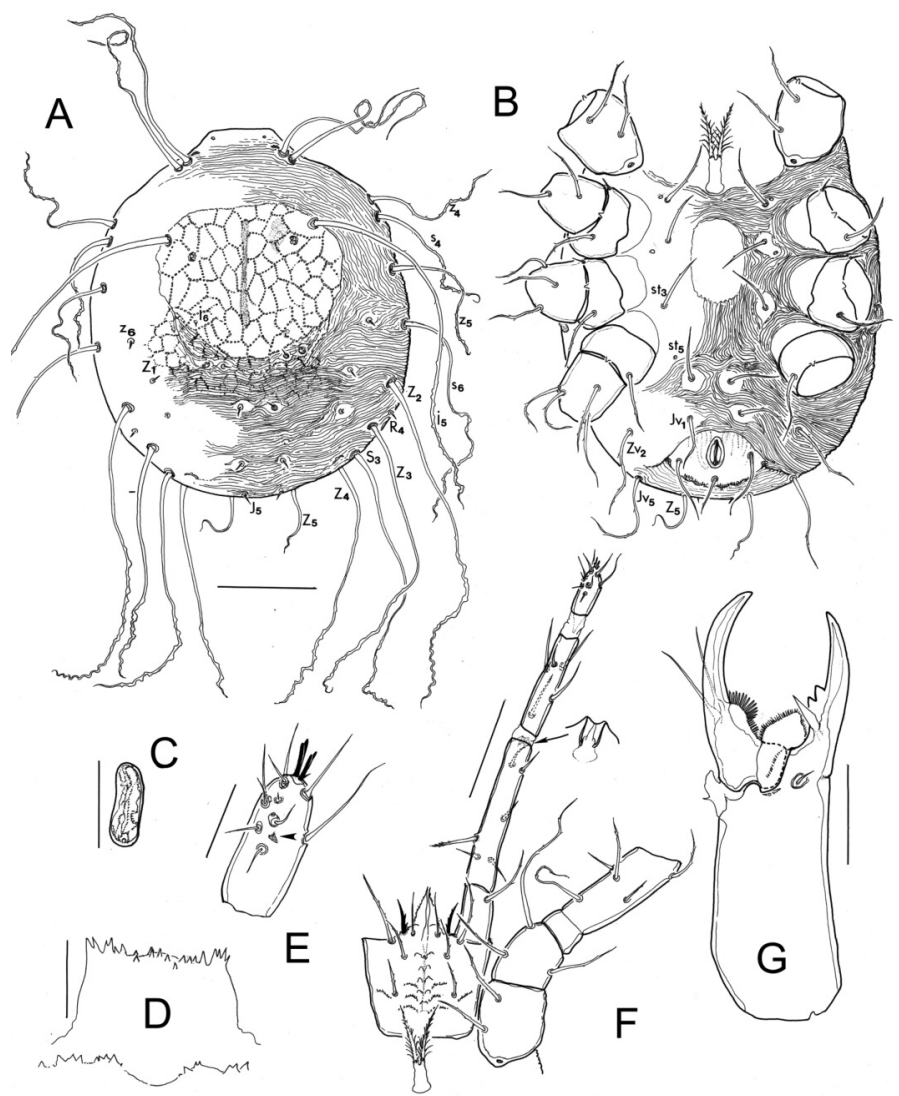

FIGURE 5. Protonymph of unidentified Heterozerconidae from Cananéia-SP, Brazil. (A) Dorsum (scale bar= $100 \mu \mathrm{m}$ ); (B) Venter (scale bar= $100 \mu \mathrm{m}$ ); (C) Peritreme (scale bar= $25 \mu \mathrm{m}$ ); (D) Gnathotectum (scale bar= 25 $\mu \mathrm{m}$ ); (E) Palpal tibiotarsus (arrow identifies rudimentary palpal apotele); (F) Subcapitulum and adjacent elements with detail of dorsodistal femoral process (scale bar= $100 \mu \mathrm{m})$; (G) Chelicera (antiaxial) (scale bar= $50 \mu \mathrm{m})$. 
than twice the trochanteral length; femur dorsodistally with a distinctive, possibly proprioreceptive, structure (lyrifissure-like structure of Gerdeman \& Klompen, 2003) (as in Fig. 5F, detail). Palpal tibiotarsus (Fig. 3C) with setation as illustrated, with undifferentiated subterminal palpal apotele (arrow) and a pair of bifurcate terminal processes that may be homologues of the nonporous palpal sensilla described for immatures of Macrocheles mycotrupetes Krantz \& Mellott (Krantz \& Royce, 1992); processes with terminally rounded tines, with a weakly defined accessory spine that appears to arise from the base of one of the tines (Fig. 3D).

Legs I (Fig. 3F) considerably longer than other legs (length 1,180), without claws; coxa with a dermal gland opening near posterior margin (cag of Gerdeman \& Klompen, 2003); tarsus I distinctly tanned throughout and comprising a basitarsus, telotarsus and distal acrotarsus; with a series of very long (ca 310-375), distally sinuous setae on the distal aspects of genu and tibia (four on genu, five on tibia), with a single similar seta on telotarsus and 2-3 shorter sinuous setae (length 125) inserted distally on the acrotarsus and one on the trochanter; other leg setae shorter (15-75), smooth or weakly ciliate; tibia and tarsus I strongly tanned, distinct in this respect from other leg segments. Legs IV longer than legs II-III (780 vs 574-655); coxal, trochanteral and femoral setae of legs II-IV mostly shorter than those of more distal segments (15-70) and without terminal sinuosity; genual, tibial and tarsal setae generally long (ca 125-170) and somewhat serpentine throughout; tarsi II-IV each with well developed paired claws inserted in a long, proximally narrowed ambulacral stalk. Chaetotaxies of genu II (2 2/1, 2 1/1) and tibiae II-III (2 1/1, 2 1/1), identical to those for deutonymph of $N$. ohioensis (Gerdeman \& Klompen, 2003); genu III with ten setae as in $N$. ohioensis, but arrangement not clear in available specimens.

PROTONYMPH (Figs. 1, 5). Idiosoma (Fig. 5A, B) similar to that of deutonymph in shape, but smaller [length $429(341-550)$, width $374(285-481)(n=6)]$.

Dorsum (Fig. 5A) with many elongate, distally sinuous marginal setae as in deutonymph; dorsal integument mostly finely striate, striate-reticulate posterior to an evanescent, reticulate prodorsal shield (length 165, width 198) that may be difficult to differentiate in uncleared specimens, median depression not extending to posterior margin; shield with only two pairs of setae, $j 5$ greatly elongate and distally sinuous ( $j 4$ absent), glands gdj5 well defined. Podonotum, including shield, with nine pairs of setae; opisthonotum with 11 pairs ( $R 4$ dorsolaterally inserted, $S 1-2$ and deutonymphal accessory setae absent).

Venter (Fig. 5B) with generally striate integument but with an unstriated region between st2-3; striae vertically oriented between clear region and st5; lyrifissures iv 3 absent as in deutonymph; some opisthogastric setae absent $(J v 2, Z v 3, S 4-5)$ or inserted dorsally (minute, putative $R 4$ inserted laterodorsally between Z2 and Z3). Anal shield distinct, anterior and posterior margins infolded in some specimens (as in illustration); without post-paranal lyrifissures (ivp), cribrum less extensive than in deutonymph (Fig. 3B), but larger than shown in the illustrated infolded example.

Peritremes (Fig. 5C) similar to but shorter than those of deutonymph (30 vs 50).

Gnathosoma (Fig. 5F, G) with subcapitulum and gnathotectum as described for deutonymph. Chelicerae (Fig. 5G) similar to but shorter than those of deutonymph (210 vs 295, including basal segment); length of second segment (including fixed digit) 123, movable digit 63. Palpi (Fig. 5E, F) unusually long but clearly shorter than those of deutonymph (385 vs 550); palpfemur nearly three times length of trochanter (163 vs 58), with dorsodistal inclusion as in deutonymph (Fig. 5F, detail). Palpal tibiotarsus (Fig. 5E) with rudimentary conical palpal apotele (arrow), paired terminal bifurcate processes and setae as illustrated.

Legs I elongate but considerably shorter (825) than in deutonymph; gland cag present near posterior margin of coxa I; sinuous setae of more distal segments as in deutonymph (Fig. 3F) but somewhat shorter; tanning mostly confined to meta- and acrotarsus (Fig. 1). Legs IV longer than legs II-III (526 vs 440-467); leg setae similar to those of deutonymph. Chaetotaxies of genu II-IV 
(1 2/0, 2 0/1) and tibiae II-IV (1 1/1, 2 1/1), identical to those of protonymph of $N$. ohioensis (Gerdeman \& Klompen, 2003).

\section{Discussion}

\section{Morphological considerations}

There are strong morphological similarities between the protonymphal and deutonymphal stages described above (hereafter referred to as Cananéia nymphs) and those of $N$. ohioensis (Gerdeman \& Klompen, 2003), but there are also notable differences. Included here are the presence in Cananéia nymphs of a discrete prodorsal shield (weakly defined in the protonymph), an anal shield, and several distally sinuous long setae on legs I and on the idiosomatic dorsum [homologous setae in $N$. ohioensis are shorter and mostly stout and spinose (120-245)]. While lyrifissures $i v 1$ are absent in all immature stages of $N$. ohioensis and $i v 3$ are present in the deutonymph, $i v 1-i v 2$ are present in both Cananéia nymphal stages and $i v 3$ are always absent. In addition, the palpi of the Cananéia nymphs are greatly elongated $(\sim 1.5$ times longer than those of protonymph and deutonymph of $N$. ohioensis), and the terminal bifurcate processes on the tibiotarsus appear longer than those of $N$. ohioensis. The presence of these unusual processes in both species (also present in the larva of $N$. ohioensis) suggests that they may emerge as a diagnostic morphological feature for all immature heterozerconids. The weak accessory spine that arises basally from one of the tines in the Cananéia nymphs has not been described for $N$. ohioensis.

\section{Behavioral considerations}

The unusually long and distally sinuous dorsal idiosomal and leg I setae in the Cananéia nymphs raise questions as to their possible function. As noted earlier, the long dorsal setae are often curved over the body in live specimens, which suggests that they may provide a degree of protection from potential predators. Nymphs in observation cells were observed to hold legs I in an elevated and arched position (Fig. 2), waving them slowly from side to side in the manner of antennae as the mites moved smoothly and deliberately over the substrate. Locomotion depends solely on legs II-IV. It appears that the long setae of legs I may aid in orienting the mite to its surroundings, locating prey or detecting the presence of potential predators.

\section{Host and habitat considerations}

Because millipedes are the most likely hosts for adult heterozerconids, we made special efforts to locate millipede nests in the original collection area near Cananéia in hopes of finding resident millipedes with attached adult heterozerconids, along with their nest-associated free-living immatures. We considered it likely that the nymphs found in our original litter samples came from nearby unseen or unrecognized nest sites and that the mites may have been foraging for prey at the edges of their nest universe. The absence of heterozerconid larvae in these samples suggested that, as with many other Mesostigmata, the larvae are weak and non-feeding and tend to remain close to their birthing substrate until the protonymphal molt (Walter \& Krantz, 2009b).

The presence of termites in our litter samples also raised the possibility that the nymphs may have come from termite nests under the litter surface, a habitat where worm lizards (Amphisbaenia) may sometimes be found. Worm lizards are fossorial neo- and paleotropical squamate reptiles that often use subterranean ant and termite nests for depositing and incubating their eggs. These nests provide a stable, protected environment for the young hatchlings (Riley et al., 1985, Andrade et al., 2006), and resident termites or ants may conceivably serve as a food source for them. Adults of the heterozerconid mite, Amheterozercon oudemansi (Finnegan), are known parasites of a variety of neotropical squamate reptiles (Fain, 1989), including the white-bellied 
worm lizard, Amphisbaena alba L., which occurs in southern Brazil. Our collecting site is well within its distribution range. Accordingly, we added subsurface termite nests to our search profile, but have thus far been unsuccessful in finding either immature heterozerconids or resident amphisbaenids in sampled nests. While there is no clear evidence that the Cananéia nymphs are A. oudemansi, both forms lack lyrifissures iv3 (Figs. 3B, 5B in this paper, and Figs. 1, 2 of Flechtmann \& Johnston, 1990) (see also morphological considerations, above).

We have not yet located millipede nests at our sampling site, but four millipedes recently collected from the litter surface and identified as a species of the spirobolid genus Rhinocricus were found to have a total of three adult female and three adult male heterozerconids attached to them. The mites were identified as a species of Heterozercon whose males correspond in most respects to the description of H. microsuctus Fain, described from a single male specimen collected from a millipede (Spirostreptus sp.) on Ihla de Maracas [sic], Brazil (Fain, 1989). However, the spermatostylus of $H$. microsuctus as illustrated by Fain is straight and subequal in length to the movable digit, while in our three male specimens it appears either straight, curved, or serpentine, and varies from slightly to considerably longer than the movable digit. Sternal lyrifissures are neither mentioned nor illustrated in Fain's description of H. microsuctus, but the unidentified males and females have all three sternal pairs (iv1-3). The unidentified females that we collected bear a general resemblance to $H$. degeneratus Berlese, which was based on a single female collected under tree bark in Matto [sic; Mato] Grosso, Brazil (Berlese, 1888). Fain (1989) noted that the female monotype of $H$. degeneratus is similar to the male of $H$. microsuctus in having small ventral suckers and deficient chaetotaxy on the lateral and posterior idiosomatic margins. In this connection, it should be mentioned that another heterozerconid species, H. latus Berlese, described from a single female taken from a termite nest in Paraguay, was distinguished from H. degeneratus only by its larger size and more subcircular shape (Berlese \& Leonardi, 1901; Silvestri, 1903). The termite nest collection site for $H$. latus may point to an amphisbaenid lizard association.

It is unfortunate that the descriptions of H. microsuctus, H.degeneratus, and H. latus are based on single specimens whose size, shape, cheliceral morphologies, or leg setal patterns may not be typical of the species they represent. Our unidentified heterozerconid adults may prove to be one of these species, but the identity of the Cananéia nymphs will not be established without rearing them to adulthood or without recovering additional nymphal specimens from a millipede or termite nest in company with their host-associated adults.

\section{Acknowledgements}

Many colleagues assisted us during the course of this investigation. We would especially like to thank Lásaro V.F. da Silva, ESALQ, USP, who collected many of our forest litter samples and assisted in establishing observation protocols at ESALQ, Piracicaba. Our thanks to Hans Klompen, Museum of Biological Diversity at Ohio State University, who kindly provided microslides of immature Narceoheterozercon ohioensis for comparative studies with the Cananéia nymphs. We are grateful to Denis V Andrade, Departamento de Zoologia, UNESP, Rio Claro, SP, Brazil, and Selma Almeida Santos, Instituto Butantan, São Paulo, Brazil, for sharing important information and ideas on the nesting habits of Brazilian amphisbaenid lizards. Our thanks also to Carmen S. Fontanetti, UNESP, Rio Claro, SP, who identified our field-collected specimens of Rhinocricus sp. Finally, we are pleased to acknowledge Jeffrey Miller, Department of Rangeland Ecology and Management, Oregon State University, Jadwiga Gebultowicz, Department of Zoology, OSU, and Chris Marshall, Department of Zoology and Curator of the Oregon State Arthropod Collection, OSU, who generously provided the time, expertise, and equipment necessary for producing and/or processing the photographs included in this paper. 


\section{References}

Alberti, G., Gerdeman, B. \& Klompen, H. (2007) Fine structure of spermiogenesis and sperm in a heterozerconid mite (Heterozerconidae; Heterozerconina; Gamasida). In: Morales-Malacara, J.B., Behan-Pelletier, V., Uekermann, E., Perez, T.M., Estrada-Venegas, E.G. \& Badii, M. (eds) Proceedings of the 11th International Congress of Acarology, Merida, pp. 557-560.

Andrade, D.V., Nascimento, L.B. \& Abe, A.S. (2006) Habits hidden underground: a review on the reproduction of the Amphisbaenia with notes on four neotropical species. Amphibia-Reptilia, 27, 207-217.

Berlese, A. (1888) Acari Austro-Americani quos collegit Aloysius Balzan. Bolletino della Societa Entomologica Italiana, 20, 171-222.

Berlese, A. (1910) Lista di nuovi specie e nuovi generi di Acari. Redia, 6, 242-271.

Berlese, A. \& Leonardi, G. (1901) Acari sud Americani. Zoologische Anzeiger, 25, 12-18.

Fain, A. (1989) Notes on mites associated with Myriapoda IV. New taxa in the Heterozerconidae (Acari, Mesostigmata). Bulletin de l'Institut Royal des Sciences Naturelles de Belguique, 59, 145-156.

Finnegan, S. (1931) On a new species of mite of the family Heterozerconidae parasitic on a snake. Proceedings of the Zoological Society of London, 4, 1349-1357.

Flechtmann, C.H.W. \& Johnston, D.E. (1990) Zeterohercon, a new genus of Heterozerconidae (Acari: Mesostigmata) and the description of Zeterohercon amphisbaenae n. sp. from Brasil. International Journal of Acarology, 16, 143-148.

Gerdeman, B. \& Alberti, G. (2007) First ultrastructural observations on the paired suckers of a heterozerconid mite (Heterozerconidae; Gamasida). In: Morales-Malacara, J.B., Behan-Pelletier, V., Ueckermann, E., Perez, T.M., Estrada-Venegas, E.G., \& Badii, M. (eds) Proceedings of the $11^{\text {th }}$ International Congress of Acarology, Merida, pp. 581-584.

Gerdeman, B.S. \& Klompen, H. (2003) A new North American heterozerconid, Narceoheterozercon ohioensis n.g., n.sp, with first description of immatures of Heterozerconidae (Acari: Mesostigmata). International Journal of Acarology, 29, 351-370.

Gerdeman, B.S., Klompen, H. \& Tanigoshi, L. (2000) Insights into the biology of a mite-millipede association. In: Wytwer, J. \& Golovatch, S. (eds) Progress in Studies on Myriapoda and Onychophora, Fragmenta Faunistica (Warszawa), 42(suppl.), 223-227.

Joly, C.A., Aidar, M.P.M., Klink, C.A., McGrath, D.G., Moreira, A.G., Moutinho, P., Nepstad, D.C., Oliveira, A.A., Pott, A., Rodal, M.J.N., Sampaio, E.V.S. (1999) Evolution of the Brazilian phytogeography classification systems: implications for biodiversity conservation. Ciência e Cultura, 51, 331-348.

Krantz, G.W. \& Royce, L.A. (1992) Descriptions of the immature stases of Macrocheles mycotrupetes Krantz and Mellott (Acari: Macrochelidae), with remarks on form, function, and phoresy. Acarologia, 33, 305-311.

Lekveishvili, M. \& Klompen, H. (2004) Phylogeny of infraorder Sejina (Acari: Mesostigmata). Zootaxa, 629, $1-19$.

Lindquist, E.E., Krantz, G.W. \& Walter, D.E. (2009) Order Mesostigmata. In: Krantz, G.W. \& Walter, D.E (eds) A manual of acarology, $3^{\text {rd }}$ edition. Texas Tech University Press, Lubbock, pp. 124-232.

Lizaso, N.M. (1979) Um novo ácaro da familia Heterozerconidae coletado sobre serpentes brasileiras. Descrição de Heterozercon elegans sp. n. (Acarina: Mesostigmata). Memórias do Instituto Butantan, 42/43, 139-144.

Norton, R.A., Kethley, J.B., Johnston, D.E. \& OConnor, B.M. (1993) Phylogenetic perspectives on genetic systems and reproductive modes of mites. In: Wrensch, D. \& Ebbert, M. (eds) Evolution and diversity of sex ratio in insects and mites. Chapman \& Hall, New York, pp. 8-99.

Riley, J., Stimson, A.F. \& Winch, J.M. (1985) A review of Squamata ovipositing in ant and termite nests. Herpetological Review, 16, 38-43.

Silvestri, F. (1903) Contribuzione alla conoscenza dei Termitidi e Termitofili dell'America occidentale. Redia, $1,1-234$.

Vitzthum, H.G. (1926) Malayische Acari. Treubia, 8, 1-198.

Walter, D.E. \& Krantz, G.W. (2009a) Collecting, Rearing, and Preparing Specimens. In: Krantz, G.W. \& Walter, D.E. (eds) A manual of acarology, $3^{\text {rd }}$ edition. Texas Tech University Press, Lubbock, pp. 83-96.

Walter, D.E. \& Krantz, G.W. (2009b) Oviposition and Life Stages. In: Krantz, G.W. \& Walter, D.E. (eds.). A manual of acarology, 3rd edition. Texas Tech University Press, Lubbock, pp. 57-63.

Walter, D.E., Lindquist, E.E., Smith, I.M., Cook, D.R. \& Krantz, G.W. (2009) Order Trombidiformes. In: Krantz, G.W. \& Walter, D.E. (eds.). A manual of acarology, $3^{\text {rd }}$ edition. Texas Tech University Press, Lubbock, pp. 233-420. 